\title{
Türkiye'deki Tüketicilerin Katı Atıkların Geri Dönüşümü Konusundaki Bilinç Düzeylerinin ve Farkındalıklarının Belirlenmesi
}

\author{
Alptekin Mert Yılmaz ${ }^{1 *}$ iD \\ ${ }^{1,3}$ Kocaeli Üniversitesi, Ziraat Fakültesi, Tarım Ekonomisi Bölümü \\ ${ }^{2}$ Çanakkale Onsekiz Mart Üniversitesi, Ziraat Fakültesi, Tarım Ekonomisi Bölümü \\ *Sorumlu yazar: alptekin.yilmaz@kocaeli.edu.tr
}

\author{
Oktay Tomar $^{3}$ iD
}

Geliş Tarihi: 16.07.2021

Kabul Tarihi: 02.11.2021

\section{$\ddot{\mathbf{O z}}$}

Her geçen gün artan dünya nüfusuna paralel olarak insan ihtiyaçlarını karşılamak niyeti ile tüketim de artmaktadır. Bununla birlikte katı atık miktarı da yükselmektedir. Geri dönüşüm, yeniden değerlendirilme imkanı olan katı atıkların, çeşitli işlemlerden geçirilerek yeniden üretim sürecine dahil edilmesidir. Geri dönüşüm programlarının başarısı, tüketicilerin katılımı ile doğru orantılıdır. Bu sebeplerle atıkların geri dönüşümünde tüketici davranışlarının araştırılması büyük öneme sahiptir. Bu çalışmanın amacı Türkiye'deki tüketicilerin katı atıkların geri dönüşümü konusundaki bilinç düzeylerinin ve farkındalıklarının belirlenmesidir. Bu çalışmada online anket formu ile elde edilen birincil veriler kullanılmıştır. Çalışma kapsamında örnekleme yöntemi kullanılarak belirlenen 415 tüketici ile anket yapılmıştır. Anketlerden elde edilen birincil veriler, temel istatistiki yöntemler ile değerlendirilmiştir. Çalışma sonuçlarına göre; Türkiye'deki tüketicilerin \%47,7'si cam eşyaları, \%41,4'ü plastik malzemeleri, \%53,5'i kağıt, karton ve türevlerini, \%41,4'ü kumaş eşyaları ve \%39,8'i elektronik eşyalar ve pilleri geri dönüşüme ayırdıklarını belirtmişlerdir. Araştırma kapsamındaki tüketicilerin bilinç düzeyleri genel olarak yüksektir. Türkiye'deki tüketicilerin geri dönüşüm ile ilgili ana sorunları; geri dönüşüm yapmak isteyen tüketiciler için sağlanan imkanların yetersiz olmasıdır. Bu nedenle özellikle yerel yönetimler kanalıyla geri dönüşüm kutularının sayılarının arttırılması ve bu kutulara her atık için ayrı bölmeye sahip olma özelliği kazandırılarak geri dönüşüm kutularının çeşitliliğinin sağlanması önerilmektedir.

Anahtar Kelimeler: Davranış, Geri Dönüşüm, Tutum, Tüketici, Türkiye.

\section{Determining The Levels Of Consciousness And Awareness Of Consumers In Turkey About Recycling Solid Waste}

\section{Abstract}

In parallel with the increasing world population, consumption is increasing to meet human needs. However, the amount of solid waste is also increasing. Recycling is the inclusion of solid wastes, which can be reused, in the re-production process by undergoing various processes. The success of recycling programs is directly proportional to the participation of consumers. For these reasons, it is of great importance to investigate consumer behavior in the recycling of waste. This study aims to determine the level of consciousness and awareness of consumers in Turkey about the recycling of solid waste. In this study, primary data obtained with an online questionnaire was used. Within the scope of the study, a survey was conducted with 415 consumers determined by using a simple random sampling method. The primary data obtained from the questionnaires were evaluated with basic statistical methods. According to the results of the study, $47.7 \%$ of consumers in Turkey stated that they separate glassware, $41.4 \%$ of consumers stated that they separate plastic materials, $53.5 \%$ of consumers stated that they separate paper, cardboard and its derivatives, $41.4 \%$ of consumers stated that they separate fabric goods and $39.8 \%$ of consumers stated that they separate electronic goods and batteries for recycling. The awareness level of the consumers within the scope of the research is generally high. The main problems of consumers in Turkey regarding recycling are; the opportunities provided for consumers who want to recycle are insufficient. For this reason, it is recommended to increase the number of recycling bins, especially through local governments, and to ensure the diversity of recycling bins by giving these bins the feature of having separate compartments for each waste.

Keywords: Behavior, Recycling, Attitude, Consumer, Turkey. 


\section{Giriş}

Dünya nüfusunun artmasıyla birlikte hemen her sektöre yönelik tüketim miktarı da artış göstermektedir (Seacat ve Northrup, 2010; Hoornweg ve Bhada-Tata, 2012; Alhassan ve ark., 2018). Buna paralel olarak, kaynakların aşırı ve sürdürülebilir olmayan şekilde kullanımı hem çevre hem de dünya ekonomisi açısından olumsuz etkilere neden olmaktadır (Björklund ve Finnveden, 2007; Song ve ark., 2015; Shevchenko ve ark., 2019). Doğanın dengesinin bilinçsiz insan davranışları ve nüfus baskısı sebebiyle bozulmasından dolayı iklim değişikliğini tetikleyen; hava, toprak ve su kirliliği, ormanların ve yaban hayatının tahrip edilmesi, çölleşme, biyoçeşitliliğin azalması, yönetilemeyen atıklar gibi sorunları beraberinde getirmektedir. Gıda ve gida dışı alanlardaki tüketim sonucu oluşan katı atıklar hem ulusal hem uluslararası çapta çözüm bekleyen bir sorundur (Botetzagiasa ve ark., 2015; Tabernero ve ark., 2015; Prats ve ark., 2020). Bundan dolayı çevre sorunları arasında yer alan katı atık yönetiminin giderek önem kazandığı belirtilmektedir. Bu sebeplerle insan ihtiyaçlarının giderilmesinde çevre dostu yöntemlerin benimsenmesi önemli görülmektedir. Atıklarla mücadelede temel olarak üç yöntemden bahsedilmektedir. 3R olarak adlandırılan bu yöntemler azaltma (reduce), yeniden kullanma (reuse) ve geri dönüşüm (recycle) olarak isimlendirilmektedir (EPA, 2021). Kat1 atıklarının en aza indirilmesinde geri dönüşüm temel işlemler arasında yer almaktadır (Hopper ve ark., 1993). İlk olarak atığın kaynağında önlenmesi, eğer kaynağında önlenemiyorsa atığın azaltılması ve eğer atık oluşumu önlenemiyorsa atıkların geri kazanılması yani geri dönüşüm yaygın olarak benimsenen anlayışlardandır. Geri dönüşüm, doğal kaynakların etkin kullanımını sağlamasının yanı sıra ekonomik açıdan da büyük önem taşımaktadır. Geri dönüşüm "Enerji geri kazanımı ve yakıt olarak kullanımı ya da dolgu yapmak üzere atıkların tekrar işlenmesi hariç olmak üzere, organik maddelerin tekrar işlenmesi dâhil atıkların işlenerek asıl kullanım amacı ya da diğer amaçlar doğrultusunda ürünlere, malzemelere ya da maddelere dönüştürüldüğü herhangi bir geri kazanım işlemini” ifade etmektedir (TCRG, 2019). Bir başka ifadeye göre geri dönüşüm yeniden değerlendirilme imkanı olan katı atıkların, çeşitli işlemlerden geçirilerek yeniden üretim sürecine dahil edilmesine denir (Bezzina ve Dimech, 2011). Geri dönüşüm sayesinde doğal kaynaklar ve ekonomik kaynaklar etkin kullanılmış olur. Bunun yanında depolama alanları ve çöp alanlarının aşırı kullanımının önlenmesinde geri dönüşüm önemli bir yöntemdir (Siwar ve ark., 2000; Ara ve ark., 2021). Atıklarla mücadelede atıkların değerlendirilmesi amacıyla kullanılan geri dönüşüm, ülkelerin çevreye verdiği önemin bir göstergesidir. Avrupa Birliği (AB) üyesi ülkeler başta olmak üzere çoğu gelişmiş ülke geri dönüşümü yaygın bir davranış olarak benimserken, Türkiye'de ise kayıt altına alınan geri dönüşüm oranı $\mathrm{AB}$ ortalamasına göre düşüktür (EUROSTAT, 2020). Geri dönüştürülen kentsel atık oranı Avrupa İstatistik Ofisi (EUROSTAT) tahminlerine göre Avrupa Birliği'nde (AB-27) ortalama \%47,7'dir (EUROSTAT, 2020). Türkiye'de ise 2019 yılında ortaya çıkan toplam belediye atığının \%11,5'inin geri dönüştürüldüğü tahmin edilmektedir (EUROSTAT, 2020). Bu verilere göre Avrupa'da geri dönüşümde ilk sıralarda yer alan ülkeler Almanya, Slovenya ve Avusturya'dır. Almanya kentsel atığının tahmini \%67,7'sini geri dönüştürmektedir (EUROSTAT, 2020). Geri dönüşüm eylemi üzerinde tüketici davranışları ana etmendir. Geri dönüşüm programlarının başarısı, tüketicilerin katılımı ile doğru orantılıdır (Woollam ve ark., 2003; Davis ve ark., 2006). Geri dönüşüm konusunda tüketicilerin tutum ve davranışlarının olumlu yönde olması durumunda çevre kirliliği azaltılabilmektedir (Bendak ve Attili, 2017). Böylece geri dönüşüm faaliyetinin hem ekonomiye hem de çevreye katkı sağlanması beklenmektedir. Geri dönüşüm faaliyeti ile geri dönüştürülebilir maddelerin tüketiciler tarafından ayrıştırılması, geri dönüşüm tesislerinde ayrıştırma yapılmasına göre daha düşük maliyetlidir. $\mathrm{Bu}$ sebeplerle atıkların geri dönüşümünde tüketici davranışlarının araştırılması büyük öneme sahiptir. Geri dönüşüm programlarının başarıya ulaşması için tüketicilerin geri dönüşüme yönelik tutumlarının anlaşılması gerekmektedir (Knussen ve ark., 2004; Tonglet ve ark., 2004). Bu kapsamda, bu çalışmanın amacı Türkiye'deki tüketicilerin katı atıkların geri dönüşümü konusundaki bilinç düzeylerinin ve farkındalıklarının belirlenmesidir.

\section{Materyal ve Yöntem}

\section{Verilerin Toplanması Sırasında Kullanılan Yöntemler}

Tarım Ekonomisi alanında ve alt dallarında (Çevre Ekonomisi) yapılması planlanan çalışmalarda, özgün veri toplamak için genellikle anket yöntemi kullanılmaktadır (Mahmud ve Osman, 2010; Botetzagias ve ark., 2015; Byrne ve O’Regan, 2014; Üstündağlı ve Güzeloğlu, 2015). 
İstatistik altyapısına sahip bilimsel veri toplama amaçlı akademik çalışmalarda ana kitlenin tamamı ile görüşmek çoğunlukla mümkün değildir (Corbin ve Strauss, 2014). Bu nedenle önceki çalışmalar incelenerek ve amaca uygun istatistiki yöntemlerle belirlenen uygun örnekleme yöntemleri ile anketlerin sayısına karar verilmelidir. Ana kitleden seçilen ve görüşülen deneklerden oluşan bu kitleye popülasyon denmektedir (Korum, 1971; Arıcı, 2006). Bu araştırmanın ana kitlesini Türkiye genelindeki tüm tüketiciler (nüfusun tamamı) oluşturmaktadır. Bu araştırmada ana kitle sınırlı ve ulaşılabilir olduğundan örnekleme ile anket sayısı belirlenmiştir. Bu çalışmanın ana materyalini Türkiye'de yaşayan tüketiciler ile online olarak gerçekleştirilecek olan anketlerden elde edilecek birincil veriler oluşturmaktadır. Bu çalışmada anket araştırmaları için en uygun örnekleme yöntemi olarak bilinen olasılıklı örnekleme yöntemi kullanılmıştır. Bu örnekleme yönteminde ana kitlenin sınırları bellidir ve bu sınırlar içinde ana kitle değerini içeren güven aralığını hesaplamak mümkündür. $\mathrm{Bu}$ da ana kitle hakkında yorum yapma imkanı sağlamaktadır (Aksoylu ve ark., 2014). Örneklem büyüklüğü aşağıdaki formül kullanılarak hesaplanmıştır:

$$
n=\frac{\mathrm{N} \cdot \mathrm{t}^{2} \cdot \mathrm{p} \cdot \mathrm{q}}{\mathrm{d}^{2} \cdot(\mathrm{N}-1)+\mathrm{t}^{2} \cdot \mathrm{p} \cdot \mathrm{q}}
$$

$\mathrm{n}=$ Örnekleme alınacak birey sayıs1,

$\mathrm{N}=$ Hedef kitledeki birey sayıs1,

$\mathrm{t}=$ Belli bir anlamlılık düzeyinde, $\mathrm{t}$ tablosuna göre bulunan teorik değer,

$\mathrm{p}=$ İncelenen olayın gerçekleşme olasılı̆̆

$\mathrm{q}=$ İncelenen olayın gerçekleşmeme olasilığı,

$\mathrm{d}=$ Olayın görülüş sıklığına göre kabul edilen \pm örnekleme hatası ( $\pm \% 5$ kabul edilmiştir) (Newbold ve ark., 1995; Baş, 2010).

Türkiye İstatistik Kurumu (TÜIK) 2020 y1lı verilerine göre Türkiye nüfusu 83.614 .000 kişi olarak belirtilmiştir (TÜiK, 2020). Bu hedef kitlede $\% 95$ güven aralığında $\alpha=0.05$ için $t$ değeri 1.96'dır. Araştırmada olayın gerçekleşme olasılığ 1 en yüksek anket sayısına ulaşabilmek için (p) ve gerçekleşmeme olasılığ 1 (q) eşit ve 0,50 olarak kabul edilmiştir. Buna göre araştırma kapsamında Türkiye genelinde online olarak minimum 383 tane anket yapılmasına karar verilmiştir. Araştırmanın anket aşamasında 415 adet geçerli ve güvenilir anket yapılmıştır. Anketler Türkiye'nin üç büyük ili olan İstanbul, Ankara ve İzmir'den katılımcılar ile illerin nüfus oranları göz önüne alınarak gerçekleştirilmiştir. Anket çalışmasının yapıldığı ilgili dönemde İstanbul, İzmir ve Ankara illeri Türkiye nüfusunun \%30,3'ünü oluşturmaktadır. Türkiye nüfusunun üçte biri araştırma kapsama alındığı için araştırmanın kapsamı Türkiye örneği olarak ifade edilmiş̧ir.

\section{Verilerin Analizi Sırasında Kullanılan Yöntemler}

Araştırmanın anket aşamasında elde edilen birincil verilerin değerlendirilmesinde temel istatistiki yöntemler (ortalama, standart sapma vb.) kullanılmıştır. Temel istatistiki yöntemlerin yanı sıra sayı ve yüzde yöntemi ile araştırma sorularına verilen cevapların frekans dağılımları verilmiştir. Ayrıca 5'li Likert Ölçekli yargılar için Likert Ölçek Ortalamasından yararlanılmıştır (Likert, 1932; Boone ve Boone, 2012; Harpe, 2015; Joshi ve ark., 2015).

\section{Bulgular ve Tartışma}

Araştırmanın bu kısmında anketlerden elde edilen verilerin temel istatistiki yöntemler ile değerlendirilmesi sonucunda elde edilen bulgular verilmiştir. Çalışmanın araştırma bulguları beş kısımdan oluşmaktadır. Buna göre ilk kısımda araştırma kapsamındaki tüketicilerin demografik özellikleri verilmiştir. İkinci kısımda araştırma kapsamındaki tüketicilerin yaşadıkları yere yakın veya günlük güzergahları üzerinde geri dönüşüm kutusu olma durumlarına göre dağılımları verilmiştir. Üçüncü kısımda araştırma kapsamındaki tüketicilerin geri dönüşüm yapma durumlarına göre dağılımları verilmiştir. Dördüncü kısımda araştırma kapsamındaki tüketicilerin bilinç düzeylerine göre dağılımları verilmiştir. Beşinci kısımda araştırma kapsamındaki tüketicilerin farkındalıklarına göre dağılımları verilmiştir.

\section{Araştırma Kapsamındaki Tüketicilerin Demografik Özellikleri}

İlk olarak araştırma kapsamındaki tüketicilerin cinsiyetlerine göre dağılımları Çizelge 1'de verilmiştir. Buna göre bu araştırma kapsamındaki tüketicilerin \%52,0'ı kadın, \%48,0'1 erkektir. 
Türkiye'deki vakıf ve devlet üniversitelerindeki 394 öğrenciyle yürütülen bir diğer çalışmada katılımcıların \%66'sı kadın, \%34'ü erkektir (Birsen, 2020). Ankara'nın Mamak, Emek ve Gaziosmanpaşa bölgelerinde tüketicilerin çevre bilincinin ölçüldüğü bir diğer çalışmada ise 399 katılımcının \%52,1'i erkek, \%47,9'u kadın olarak belirlenmiştir (Yaraş ve ark., 2011). Sakarya Üniversitesi'nde öğrenim gören 355 öğrencinin geri dönüşüme yönelik farkındalıklarını tespit etmek amacıyla yapılan bir çalışmada katılımcıların \%57,5'i kadın, \%42,5'i erkektir (Ak ve Genç, 2018). Amerika Birleşik Devletleri'nde yer alan Midwestern Üniversitesi'nde 1560 katılımcıyla yürütülen bir çalışmada katılımcıların \%68,7'si, \%28,4'ü erkek olarak (\%2,7'si diğer veya cinsiyet belirtmeyenler) tespit edilmiştir (Arain ve ark., 2020). Başev (2016) tarafından geri dönüşüm davranış1 ve bu davranış1 etkileyen faktörleri tespit etmek amaciyla çeşitli ülkelerden 66 öğrenciye yönelik düzenlenen bir çalışmada katılımcıların \%53'ü erkek, \%47'si kadın olarak belirlenmiştir. Bayraktar ve Çobanoğlu (2016) tarafindan Türkiye'deki tüketicilerin 2006 ve 2012 yılları arasındaki geri dönüşüm davranışlarının karşılaştııılması amacıyla İstanbul'da düzenlenen çalışmada 2006 yılında 400, 2012 y1lında ise 337 geçerli ankete ulaşılmıştır. Buna göre 2006 yılında katılımcıların \%50'si kadın, \%50'si erkek olarak belirlenirken 2012 yılında katılımcıların \%45,8'i erkek, \%54,2'si kadın olarak tespit edilmiştir. Birleşik Arap Emirlikleri'nde yaşayan tüketicilerin geri dönüşüme yönelik tutum ve davranışlarını belirlemek üzere 989 tüketicinin katıldığı çalışmada tüketicilerin \%44'ü erkek, \%56's1 ise kadın olarak ortaya konmuştur (Bendak ve Attili, 2017). Tonglet ve arkadaşları (2004) tarafindan Brixworth, İngiltere'de geri dönüşüm davranışlarını belirlemek amacıyla 191 katılımcıya yönelik düzenlenen çalışmada katılımcıların \%35'i erkek, \%65'i kadın olarak belirlenmiştir.

Çizelge 1. Araştırma kapsamındaki tüketicilerin cinsiyetlerine göre dağılımları (\%)

\begin{tabular}{lll}
\hline Cinsiyet & Sayı & Yüzde (\%) \\
\hline Kadın & 216 & 52,0 \\
Erkek & 199 & 48,0 \\
Toplam & 415 & 100,0 \\
\hline
\end{tabular}

Araştırma kapsamındaki tüketicilerin yaşları anket formunda temel istatistiki hesapları yapabilmek amaciyla sürekli değişken türünde sorulmuştur. Buna göre yaş değişkeninin sürekli halinden elde edilen verilere göre tüketicilerin yaş ortalaması 28,8 ve standart sapmas1 9,2 olarak hesaplanmıştır. Ayrıca ankete katılan tüketiciler arasında en genç olan 18 ve en yaşlı olan 65 yaşındadır. Daha sonra yaş verileri kesikli değişken olarak gruplandırılarak Çizelge 2'de verilmiştir. Buna göre araştırma kapsamındaki tüketicilerin \%53,5'i 18 ile 28 yaş arasında, \%32,5'i 29 ile 38 yaş arasında, \%10,1'i 39 ile 48 yaş arasında, \%2,9'u 49 ile 58 yaş arasında ve \%1,0'1 58 yaş veya üzerindedir. Sakarya Üniversitesi’nde öğrenim gören 355 öğrencinin katıldığı bir çalışmada katılımcıların \%95,5'inin 18-24 yaş aralığında olduğu tespit edilmiştir (Ak ve Genç, 2018). Başev (2016) tarafından çevrimiçi olarak uygulanan ve çeşitli ülkelerden 66 öğrencinin katılım sağladığı bir çalışmada katılımcıların \%77'sinin 18-30, \%18'inin 31-45, \%5'inin ise 46-55 yaş aralığında olduğu belirlenmiştir. Malta' da yaşayan 400 kişinin katılım sağladığı bir çalışmada katılımcıların \%23,5'inin 18-29 yaş arasında, \%32,5'inin 30-44 yaş arasında, \%44'ünün 45-64 yaş arasında olduğu tespit edilmiştir (Bezzina ve Dimech, 2011). Türkiye'deki devlet ve vakıf üniversitelerinde öğrenim gören 394 öğrencinin geri dönüşüm davranışının üniversite türüne ve cinsiyete göre değişimini inceleyen bir çalışmada katılımcılar doğum tarihlerine göre sınıflandırılmış olup katılımcıların \%59,4'ü 1995 ve üzeri, \%36,5'I 1980-1994 yılları aras1, \%4,1'i ise 1979 ve altı doğum tarihlidir (Birsen, 2020). Brixworth, İngiltere'de 191 katılımcıyla yapılan anket çalışması ile geri dönüşüm davranışının belirleyicilerinin araştırıldığ bir çalışmada tüketicilerin \%2'sinin 18-24 yaş arasında, \%34'ünün 25-39 yaş arasında, \%47'sinin 40-64 yaş arasında, \%17'sinin 65 yaş ve üzerinde olduğu tespit edilmiştir (Tonglet ve ark., 2004).Yaraş ve arkadaşları (2011) tarafından Ankara'da üç farklı bölgede yer alan alışveriş merkezlerinde uygulanan ve 399 katılımcıya ulaşılan anket çalışmasında katılımcıların \%3,5'inin 20 yaş altında, \%15'inin 20-29 yaş arasında, \%47,6'sının 30-39 yaş arasında, \%20,3'ünün 40-49 yaş arasında, \%9,8'inin 50-59 yaş arasında, \%3,8'inin 60 yaş ve üzeri olduğu ortaya konmuştur. 
Çizelge 2. Araştırma kapsamındaki tüketicilerin yaş aralıklarına göre dağılımları (\%)

\begin{tabular}{lll}
\hline Yaş Aralığı & Sayı & Yüzde $(\%)$ \\
\hline 18 ile 28 yaş arası & 222 & 53,5 \\
29 ile 38 yaşarası & 135 & 32,5 \\
39 ile 48 yaş aras1 & 42 & 10,1 \\
49 ile 58 yaş arası & 12 & 2,9 \\
58 yaş üzeri & 4 & 1,0 \\
Toplam & 415 & 100,0 \\
\hline
\end{tabular}

Yaş Min. $=18, \operatorname{Max}=65$, Ortalama $=28,8$, Standart Sapma=9,2

Araştırma kapsamındaki tüketicilerin eğitim seviyelerine göre dağılımları Çizelge 3 'te verilmiştir. Buna göre tüketicilerin \%1,0'1 ilkokul mezunu, \%0,5'i ortaokul mezunu, \%26,2'si lise mezunu, \%9,2'si üniversite öğrencisi, \%44,7'si üniversite mezunu, \%15,7'si yüksek lisans mezunu ve \% 2,7'si doktora mezunudur. Çeşitli ülkelerden 66 öğrenciyle yapılan bir çalışmada katılımcıların \%9'u lisans, \%54'ü lisansüstü (postgraduate), \%26'sı doktora seviyesindedir. Katılımcıların \%11'i bu soruya yanıt vermemiştir (Başev, 2016). Bayraktar ve Çobanoğlu (2016) tarafindan Türkiye'deki tüketicilerin 2006 ve 2012 yılları arasındaki geri dönüşüm davranışlarının karşılaştırılması amacıyla İstanbul'da düzenlenen çalışmada 2006 y1lında 400, 2012 yılında ise 337 geçerli ankete ulaşılmıştır. Buna göre katılımcıların 2006 yılında \%64,2'si üniversite derecesi veya üstü, \%35'8'i üniversite derecesinden daha düşük eğitim seviyesine sahipken 2012 yılında katılımcıların \%70,5'i üniversite derecesi veya daha üstü, $\% 29,5^{\prime}$ 'i üniversite derecesinden daha düşük eğitim seviyesine sahiptir. Tonglet ve arkadaşları (2004) tarafından İngiltere'de 191 kişiyle yapılan bir diğer çalışmada ise katılımcıların \%33'ü üniversite mezunu olarak belirlenmiştir. Yaraş ve arkadaşları (2011) tarafindan Ankara'da 399 kişiyle yapılan çalışmada katılımcıların \%35,8'i ilköğretim, \%21,6's1 lise, \%39,6's1 üniversite, $\% 3$ 'ü ise lisansüstü derecesine sahiptir.

Çizelge 3. Araştırma kapsamındaki tüketicilerin eğitim seviyelerine göre dağılımları (\%)

\begin{tabular}{lll}
\hline Eğitim Seviyesi & Sayı & Yüzde (\%) \\
\hline İlkokul Mezunu & 4 & 1,0 \\
Ortaokul Mezunu & 2 & 0,5 \\
Lise Mezunu & 109 & 26,2 \\
Üniversite Öğrencisi & 38 & 9,2 \\
Üniversite Mezunu & 186 & 44,7 \\
Yüksek Lisans Mezunu & 65 & 15,7 \\
Doktora Mezunu & 11 & 2,7 \\
Toplam & 415 & 100,0 \\
\hline
\end{tabular}

Araştırma kapsamındaki tüketicilerin mesleklerine veya uğraşılarına göre dağılımları Çizelge 4'te verilmiştir. Buna göre tüketicilerin \%35,4'ü öğrenci, \%25,1'i özel sektör çalışanı, \%16,4'ü memur, \%14,2'si serbest meslek, \%7,2'si işsiz ve \%1,7'si emeklidir. Çeşitli ülkelerden 66 öğrencinin katılım sağladığı bir çalışmada katılımcıların \%27'si işsiz, \%17'si tam zamanlı çalışan, \%53'ü yarı zamanlı çalışan olarak belirlenmiştir. Katılımcıların \%3'ü bu soruya yanıt vermemiştir (Başev, 2016). Bayraktar ve Çobanoğlu (2016) tarafindan Türkiye'deki tüketicilerin 2006 ve 2012 yılları arasındaki geri dönüşüm davranışlarının karşılaştırılması amacıyla İstanbul'da düzenlenen çalışmada 2006 yılında 400, 2012 yılında ise 337 geçerli ankete ulaşılmışıtır. Buna göre katılımcıların 2006 yılında \%52,3'ü tam zamanlı çalışan, \%11,3'ü yarı zamanlı çalışan, \%31,2'si işsiz, \%5,2'si emekli olarak belirlenmiştir. 2012 yılında ise katılımcıların \%53,1'i tam zamanlı çalışan, \%13,4'ü yarı zamanlı çalışan, \%29,5'i işsiz ve \%4'ü emekli olarak tespit edilmiştir. Avustralya'da inşaat sektörünün geri dönüşüm davranışlarının araştırıldığı bir çalışmada 361 geçerli ankete ulaşılmıştır. Buna göre katılımcıların yaklaşık \%10,8'i geliştirici, yaklaşık \%48,6'sı danışman, yaklaşık \%12,2'si yüklenici, yaklaşık \%24,3'ü taşeron ve yaklaşık \%4,1'i tedarikçi olarak ortaya konmuştur (Tam ve ark., 2018).

Çizelge 4. Araştırma kapsamındaki tüketicilerin mesleklerine/uğraşılarına göre dağılımları (\%)

\begin{tabular}{lll}
\hline Meslek/İş Grubu & Sayı & Yüzde (\%) \\
\hline Öğrenci & 147 & 35,4 \\
Özel Sektör Çalışanı & 104 & 25,1 \\
Memur & 68 & 16,4 \\
Serbest Meslek & 59 & 14,2 \\
İşsiz & 30 & 7,2 \\
Emekli & 7 & 1,7 \\
Toplam & 415 & 100,0 \\
\hline
\end{tabular}


Araştırma kapsamındaki tüketicilerin medeni durumlarına göre dağılımları Çizelge 5'te verilmiştir. Buna göre araştırma kapsamındaki tüketicilerin \%65,5'i bekar ve \%34,5'i evlidir. Farklı ülkelerden 66 öğrencinin katılım sağladığı bir çalışmada katılımcıların \%71'i bekar, \%22'si evli olarak tespit edilmiştir. Katılımcıların \%1'i bu soruya yanıt vermezken \%6'sının birlikte yaşadığı belirlenmiştir (Başev, 2016). Bayraktar ve Çobanoğlu (2016) tarafindan Türkiye'deki tüketicilerin 2006 ve 2012 yılları arasındaki geri dönüşüm davranışlarının karşılaştırılması amacıyla İstanbul'da düzenlenen çalışmada 2006 yılında 400, 2012 yılında ise 337 geçerli ankete ulaşılmıştır. Buna göre katılımcıların 2006 yılında \%66,3'ünün bekar, \%33'7'sinin bekar olduğu belirlenmiştir. 2012 yılında ise katılımcıların \%63,4'ünün bekar, \%36,6'sının evli olduğu tespit edilmiştir. Birleşik Arap Emirlikleri'nde 989 katılımcıya ulaşılan bir çalışmada katılımcıların \%32,3'ünün bekar, \%66,6'sının evli, \%0,8'inin boşanmış olduğu ortaya konmuştur. Katılımcıların \%0,3'ü ise bu soruda diğer olarak sınıflandırılmıştır (Bendak ve Attili, 2017). Tonglet ve arkadaşları (2004) tarafından Brixworth, İngiltere'de uygulanan ve 191 katılımcıya ulaşılan çalışmada katılımcıların \%9'unun bekar, \%78'inin evli, \%5'inin boşanmış, \%6'sının dul olduğu tespit edilmiştir. Katılımcıların \%2'si bu soruya yanıt vermemiştir.

Çizelge 5. Araştırma kapsamındaki tüketicilerin medeni durumlarına göre dağılımları (\%)

\begin{tabular}{lll}
\hline Medeni Durum & Say1 & Yüzde (\%) \\
\hline Bekar & 272 & 65,5 \\
Evli & 143 & 34,5 \\
Toplam & 415 & 100,0 \\
\hline
\end{tabular}

Araştırma kapsamındaki tüketicilerin çocuk sahibi olup olmadıklarına göre dağılımları Çizelge 6'da verilmiştir. Buna göre tüketicilerin \%75,4'ünün çocuğu yok iken \%24,6'sının çocuğu vardır. Başev (2016) tarafından yapılan ve çeşitli ülkelerden 66 öğrencinin katılım sağladığı bir çalışmada katılımcıların \%83'ünün çocuğu yokken, \%17'sinin çocuğu vardır. Bayraktar ve Çobanoğlu (2016) tarafından Türkiye'deki tüketicilerin 2006 ve 2012 yılları arasındaki geri dönüşüm davranışlarının karşılaştırılması amacıyla İstanbul'da düzenlenen çalışmada 2006 yılında 400, 2012 yılında ise 337 geçerli ankete ulaşılmıştır. Buna göre katılımcıların 2006 yılında \%30,5'inin çocuğu varken, \%69,5'inin çocuğu yoktur. 2012 yılında ise katılımcıların \%29,2'sinin çocuğu varken, \%70,8'inin çocuğu yoktur. Tonglet ve arkadaşları (2004) tarafindan İngiltere'de 191 geçerli ankete ulaşılan çalışmada katılımcıların \%58'inin evde çocuğu yokken, \%21'inin 12 yaş altı çocuğu, \%15'inin ise 1218 yaş arası çocuğu vardır. Katılımcıların \%6'sı bu soruya yanıt vermemiştir.

Çizelge 6. Araştırma kapsamındaki tüketicilerin çocuk sahibi olup olmadıklarına göre dağılımları (\%)

\begin{tabular}{lll}
\hline Çocuk Sahibi Olma Durumu & Say1 & Yüzde (\%) \\
\hline Hayır & 313 & 75,4 \\
Evet & 102 & 24,6 \\
Toplam & 415 & 100,0 \\
\hline
\end{tabular}

Araştırma kapsamındaki tüketicilerin hanelerinde kişi sayısı (kendileri de dahil olmak üzere) sürekli değişken olarak sorulmuş ve daha sonra kesikli değişken olması için gruplandırılmıştır (Çizelge 7). Tüketicilerin hanelerinde kendileri dahil yaşayan kişi sayısı ortalama 3,3 olarak hesaplanırken, standart sapması 1,4 olarak hesaplanmıştır. Ayrıca tüketicilerin hanelerinde yaşayan kişi sayısı en az 1, en çok 12 olarak tespit edilmiştir. Araştırma kapsamındaki tüketicilerin \% 56,2'si 1 ile 3 kişilik ailede, \% 42,4'ü 4 ile 6 kişilik ailede ve \% 1,4'ü 7 ve üzeri kişilik ailede yaşamaktadır. Başev (2016) tarafından yapılan ve çeşitli ülkelerden 66 öğrencinin katılım sağladığı bir çalışmada katılımcıların \%53'ü tek yaşarken, \%15'inin evinde 1 aile üyesi, \%17'sinin evinde 2 aile üyesi, $\% 6$ 'sının evinde 3 aile üyesi, \%3'ünün evinde 4 aile üyesi, \%6'sının evinde 4 'ten daha fazla aile üyesinin bulunduğu tespit edilmiştir. Birsen (2020) tarafından Türkiye'deki devlet ve vakıf üniversitelerinde öğrenim gören öğrencilerin geri dönüşüm davranışları 394 öğrencinin katıldığı bir çalışmayla araştırılmıştır. Buna göre katılımcıların \%31,5'inin evinde 1-3 kişi, \%49,5'inin evinde 4-5 kişi, \%19'unun evinde 6 ve üzerinde kişi yaşamaktadır. 
Çizelge 7. Araştırma kapsamındaki tüketicilerin evlerinde kendileri dahil yaşayan toplam kişi sayısına göre dağılımları (\%)

\begin{tabular}{lll}
\hline Kişi Sayısı Aralı̆̆ & Sayı & Yüzde (\%) \\
\hline 1 ile 3 kişi arası & 233 & 56,2 \\
4 ile 6 kişi arası & 176 & 42,4 \\
7 ve üzeri & 6 & 1,4 \\
Toplam & 415 & 100,0 \\
\hline
\end{tabular}

Hanedeki kişi sayıs1 Min=1, Max=12, Ortalama=3,3, Standart Sapma= 1,4

Araştırma kapsamındaki tüketicilerin aylık kişisel gelirlerine göre dağılımları Çizelge 8'de verilmiştir. Buna göre tüketicilerin \%36,6'sının kişisel geliri yoktur. Tüketicilerin \%13,0'1nın 2.000 TL veya daha az, \%14,9'unun 2.001 ile 4.000 TL aras1, \%16,9'unun 4.001 ile 6.000 TL aras1, $\% 10,1$ 'inin 6.001 ile $8.000 \mathrm{TL}$ arası, \%8,0'ının ise $8.001 \mathrm{TL}$ ve üzeri kişisel geliri vardır. Anket kapsamındaki tüketicilerin $\% 0,5$ 'i ise bu soruya yanıt vermemiştir.

Çizelge 8. Araştırma kapsamındaki tüketicilerin aylık kişisel gelirlerine göre dağılımları (\%)

\begin{tabular}{lll}
\hline Aylık Kişisel Gelir & Sayı & Yüzde (\%) \\
\hline Şahsi gelirim yok & 152 & 36,6 \\
2.000 TL veya daha az & 54 & 13,0 \\
2.001 ile 4.000 TL aras1 & 62 & 14,9 \\
4.001 ile 6.000 TL aras1 & 70 & 16,9 \\
6.001 ile 8.000 aras1 & 42 & 10,1 \\
8.001 TL ve üzeri & 33 & 8,0 \\
Yanit Yok & 2 & 0,5 \\
Toplam & 415 & 100,0 \\
\hline
\end{tabular}

Araştırma kapsamındaki tüketicilerin aylık toplam hane gelirlerine göre dağılımları Çizelge 9'da verilmiştir. Buna göre tüketicilerin \%28,6'sının 5.000 TL veya daha az, \%41,2'sinin 5.001 ile 10.000 TL arasinda, \%14,0'ının 10.001 ile 15.000 arasinda, \%5,8'inin 15.001 ile 20.000 TL arasinda, $\% 2,4$ 'ünün 20.001 ile $25.000 \mathrm{TL}$ arasında, \%5,1'inin ise $25.001 \mathrm{TL}$ ve üzeri aylık toplam hane geliri vardır. Tüketicilerin $\% 2,9$ 'u ise bu soruya yanıt vermemiştir.

Çizelge 9. Araştırma kapsamındaki tüketicilerin aylık toplam hane gelirlerine göre dağılımları (\%)

\begin{tabular}{lll}
\hline Aylık Toplam Hane Geliri & Say1 & Yüzde (\%) \\
\hline 5.000 TL veya daha az & 119 & 28,6 \\
5.001 ile 10.000 TL arasında & 171 & 41,2 \\
10.001 ile 15.000 TL arasında & 58 & 14,0 \\
15.001 ile 20.000 TL arasında & 24 & 5,8 \\
20.001 ile 25.000 TL arasında & 10 & 2,4 \\
25.001 TL ve üzeri & 21 & 5,1 \\
Yanit yok & 12 & 2,9 \\
Toplam & 415 & 100,0 \\
\hline
\end{tabular}

\section{Araştırma Kapsamındaki Tüketicilerin Yaşadıkları Yere Yakın veya Günlük} Güzergahları Üzerinde Geri Dönüşüm Kutusu Olması Durumlarına Göre Değişkenler

Araştırma kapsamındaki tüketicilerin yaşadıkları yere yakın veya günlük güzergahları üzerinde geri dönüşüm kutusu olma durumlarına göre dağılımları Çizelge 10'da verilmiştir. Cam, kağıt ve plastik atıklar, eski giysiler ve ayakkabılar, pil çöpü geri dönüşüm kutusu ve son olarak elektronik atık toplama kutusu olmak üzere dört soru sorulmuştur. Buna göre cam, kağıt ve plastik atıkları ayrı ayrı atabileceği geri dönüşüm kutularının yerini bilip kullandığını beyan eden tüketicilerin oranı \%40,2, eski giysilerini ve ayakkabılarını ihtiyacı olanlara ulaştırmak amaciyla giysi kumbaralarının yerini bilip kullananların oranı $\% 48,4$, pil çöpü geri dönüşüm kutusunun yerini bilip kullananların oran $\% 30,1$ ve elektronik atık toplama kutusunun yerini bilip kullananların oran $\% 8,9$ 'dur. Fakat araştırma kapsamındaki tüketicilerin $\% 51,1$ 'inin yaşadığı yere yakın veya günlük güzergahı üzerinde elektronik atık toplama kutusu olmadığı tespit edilmiştir. Bunun yanında araştırma kapsamındaki tüketicilerin yaklaşık üçte birinin $(\% 32,5)$ yaşadığ 1 yere yakın veya günlük güzergahı üzerinde pil çöpü geri dönüşüm kutusu olmadığ 1 ortaya konmuştur. Üniversite öğrencilerinin geri dönüşüm bilincini araştırmak üzere Sakarya Üniversitesi Siyasal Bilgiler Fakültesi'nde öğrenim gören 355 öğrenciyle yapılan bir diğer çalışmada öğrencilerin yaklaşık \%68'inin yakınında geri dönüşüm 
kutusu olmadığı tespit edilmiştir (Ak ve Genç, 2018). Amerika Birleşik Devletleri’nde yer alan Midwestern Üniversitesi'nde 1560 katılımcıyla yürütülen bir diğer çalışmada elektronik atıklarını geri dönüştürmeyenlerin yaklaşık \%80'inin yakınlarında yer alan geri dönüşüm tesislerinden haberdar olmadıkları belirlenmiştir (Arain ve ark., 2020).

Çizelge 10. Araştırma kapsamındaki tüketicilerin yaşadıkları yere yakın veya günlük güzergahları üzerinde geri dönüşüm kutusu olma durumlarına göre dağılımları (\%)

\begin{tabular}{|c|c|c|c|c|c|c|c|c|c|c|}
\hline \multirow[t]{2}{*}{$\mathrm{N}=415$} & \multicolumn{2}{|c|}{$\begin{array}{l}\text { Evet Ama Sadece } \\
\text { Görüyorum } \\
\text { (1) }\end{array}$} & \multicolumn{2}{|c|}{$\begin{array}{l}\text { Evet Yerini } \\
\text { Biliyor ve } \\
\text { Kullanıyorum } \\
\text { (2) }\end{array}$} & \multicolumn{2}{|c|}{$\begin{array}{l}\text { Bilmiyorum } \\
\text { Varsa da } \\
\text { Görmedim } \\
\text { (3) }\end{array}$} & \multicolumn{2}{|c|}{$\begin{array}{c}\text { Yok ama Ben } \\
\text { Uzak Olanlara } \\
\text { veya Günlük } \\
\text { Geçiş } \\
\text { Güzergahımda } \\
\text { Olmayanlara Bile } \\
\text { Özellikle Yolumu } \\
\text { Değiştirip } \\
\text { Gidiyorum } \\
\text { (4) } \\
\end{array}$} & \multicolumn{2}{|c|}{$\begin{array}{l}\text { Hayır Yok } \\
\text { (5) }\end{array}$} \\
\hline & Say1 & $\begin{array}{l}\begin{array}{l}\text { Yüzde } \\
(\%)\end{array} \\
\end{array}$ & Say1 & $\begin{array}{l}\begin{array}{l}\text { Yüzde } \\
(\%)\end{array} \\
(\%)\end{array}$ & Say1 & $\begin{array}{l}\begin{array}{l}\text { Yüzde } \\
(\%)\end{array} \\
\end{array}$ & Say1 & $\begin{array}{l}\text { Yüzde } \\
(\%)\end{array}$ & Say1 & $\begin{array}{l}\begin{array}{l}\text { Yüzde } \\
(\%)\end{array} \\
\end{array}$ \\
\hline $\begin{array}{l}\text { Yaşadığı̆ıı yere } \\
\text { yakın veya günlük } \\
\text { güzergahlarınız } \\
\text { üzerinde } \\
\text { ulaşabileceğiniz } \\
\text { mesafede cam, } \\
\text { kağıt ve plastik } \\
\text { atıkları ayrı ayrı } \\
\text { atabileceğiniz geri } \\
\text { dönüšüm kutuları } \\
\text { var mıdır? }\end{array}$ & 51 & 12,4 & 167 & 40,2 & 57 & 13,7 & 28 & 6,7 & 112 & 27,0 \\
\hline $\begin{array}{l}\text { Yaşadığınız yere } \\
\text { yakın veya günlük } \\
\text { güzergahlarınız } \\
\text { üzerinde } \\
\text { ulaşabileceğiniz } \\
\text { mesafede eski } \\
\text { giysilerinizi, } \\
\text { ayakkabılarınızı } \\
\text { ihtiyacı olan } \\
\text { kişilere ulaştırmak } \\
\text { amacı ile giysi } \\
\text { kumbaraları var } \\
\text { mıdır? }\end{array}$ & 75 & 18,2 & 201 & 48,4 & 42 & 10,1 & 18 & 4,3 & 79 & 19,0 \\
\hline $\begin{array}{l}\text { Yaşadığınız yere } \\
\text { yakın veya günlük } \\
\text { güzergahlarınız } \\
\text { üzerinde } \\
\text { ulaşabileceğiniz } \\
\text { mesafede yakın } \\
\text { pil çöpü geri } \\
\text { dönüşü kutusu } \\
\text { var mıdır? }\end{array}$ & 34 & 8,2 & 125 & 30,1 & 94 & 22,7 & 27 & 6,5 & 135 & 32,5 \\
\hline $\begin{array}{l}\text { Yaşadığınız yere } \\
\text { yakın veya günlük } \\
\text { güzergahlarınız } \\
\text { üzerinde } \\
\text { ulaşabileceğiniz } \\
\text { mesafede } \\
\text { elektronik atık } \\
\text { toplama kutusu } \\
\text { var mıdır? }\end{array}$ & 11 & 2,6 & 37 & 8,9 & 141 & 34,0 & 14 & 3,4 & 212 & 51,1 \\
\hline
\end{tabular}


Türkiye'de Fen Bilgisi öğretmenliği bölümünde öğrenim gören 315 öğrencinin katıldığı bir diğer çalışmada ise birinci sınıf öğrencilerinin \%41,4'ünün, ikinci sınıf öğrencilerinin \%36,2'sinin, üçüncü sınıf öğrencilerinin \%48,8'inin, dördüncü sınıf öğrencilerinin ise \%51,1'inin ikamet ettikleri yere 250 metre veya daha yakın mesafede geri dönüşüm konteyneri olduğu belirlenmiştir (Harman ve Çelikler, 2018). Türkiye'deki tüketicilerin geri dönüşüm konusundaki davranışlarının yıllara göre değişiminin incelendiği bir çalışmada 2006 y1lında geri dönüșüm konteynerlerinin çok uzak olduğunu düşünen tüketicilerin oranı \%62,1 olarak belirlenirken 2012 y1lında bu oran \%54,3 olarak tespit edilmiştir (Bayraktar ve Çobanoğlu, 2016).

\section{Değişkenler \\ Araştırma Kapsamındaki Tüketicilerin Geri Dönüşüm Yapma Durumlarına Göre \\ Araştırma kapsamındaki tüketicilerin geri dönüşüm yapma durumlarına göre dağılımları} Çizelge 11'de verilmiştir. Buna göre cam eşyalar/atıklar için geri dönüşüm yaptığını belirtenlerin oranı $\% 47,7$, bazen geri dönüşüm yaptığını belirtenlerin oran $\% 27,5$ ve geri dönüşüm yapmayanların oranı ise $\% 24,8$ 'dir. Plastik malzemeler için geri dönüşüm yaptığını belirtenlerin oranı $\% 41,4$, bazen geri dönüşüm yaptığını belirtenlerin oranı $\% 32,3$ ve geri dönüşüm yapmayanların oranı ise $\% 26,3$ 'tür. Kağıt, karton ve türevleri için geri dönüşüm yaptığııı belirtenlerin oran1 $\% 53,5$, bazen geri dönüşüm yaptığını belirtenlerin oranı $\% 29,2$ ve geri dönüşüm yapmadığını belirtenlerin oranı ise $\% 17,3$ 'tür. Kumaş eşyalar için geri dönüşüm yaptığını belirtenlerin oran $1 \% 41,4$, bazen geri dönüşüm yaptığını belirtenlerin oran $\% 27,5$ ve geri dönüşüm yapmadığını belirtenlerin oranı ise $\% 31,1$ 'dir. Elektronik eşyalar ve piller için geri dönüşüm yaptığını belirtenlerin oranı $\% 39,8$, bazen geri dönüşüm yaptığını belirtenlerin oranı \%28,9, geri dönüşüm yapmadığını belirtenlerin oranı \%31,3'tür. Çevre Ajansı tarafından 2002 yılında İngiltere ve Galler'de 2516 katılımcıyla yürütülen bir çalışmada geri dönüşüme istekli olmayanların \%20-25 oranında olduğu aktarılmıştır (Tonglet ve ark., 2004). Türkiye'de Fen Bilgisi öğretmenliği okuyan 315 öğrencinin katılım sağladığı bir başka çalışmada öğrencilerin yaklaşık \%69'unun katı atıkları ayrıştırmadığı belirlenmiştir (Harman ve Çelikler, 2018). Afrika'da yapılan bir çalışmada hanelerin geri dönüşüme katılım oranının düşük seviyede olduğu tespit edilmiştir (Kamara, 2006). Değişik ülkelerden 66 öğrencinin katılım sağladığı bir diğer çalışmada katılımcıların \%66,1'inin geri dönüşüm davranışının bulunduğu ortaya konmuştur (Başev, 2016). Birleşik Arap Emirlikleri'nde 989 tüketicinin katılım sağladığı bir çalışmada araştırma kapsamındaki tüketicilerin \%80'inin kullandığı ürünlerin \%10'undan daha az bir miktarını geri dönüştürdüğü belirlenmiştir (Bendak ve Attili, 2017).

Çizelge 11. Araştırma kapsamındaki tüketicilerin geri dönüşüm yapma durumlarına göre dağılımları (\%)

\begin{tabular}{|c|c|c|c|c|c|c|c|c|c|}
\hline \multirow[t]{2}{*}{$\mathrm{N}=415$} & & \multicolumn{2}{|c|}{$\begin{array}{l}\text { Evet } \\
(1)\end{array}$} & \multicolumn{2}{|c|}{$\begin{array}{l}\text { Bazen } \\
(2)\end{array}$} & \multicolumn{2}{|c|}{$\begin{array}{l}\text { Hayır } \\
(3)\end{array}$} & \multicolumn{2}{|c|}{ Toplam } \\
\hline & & Say1 & Yüzde (\%) & Say1 & Yüzde (\%) & Say1 & $\begin{array}{c}\text { Yüzde } \\
(\%)\end{array}$ & Sayı & $\begin{array}{c}\text { Yüzde } \\
(\%)\end{array}$ \\
\hline Cam eşyalar/atıklar & & 198 & 47,7 & 114 & 27,5 & 103 & 24,8 & 415 & 100,0 \\
\hline Plastik malzemeler & & 172 & 41,4 & 134 & 32,3 & 109 & 26,3 & 415 & 100,0 \\
\hline $\begin{array}{l}\text { Kağıt, } \\
\text { türevleri }\end{array}$ & ve & 222 & 53,5 & 121 & 29,2 & 72 & 17,3 & 415 & 100,0 \\
\hline Kumaş eşyalar & & 172 & 41,4 & 114 & 27,5 & 129 & 31,1 & 415 & 100,0 \\
\hline $\begin{array}{l}\text { Elektronik eşyalar } \\
\text { piller }\end{array}$ & ve & 165 & 39,8 & 120 & 28,9 & 130 & 31,3 & 415 & 100,0 \\
\hline
\end{tabular}

\section{Araştırma Kapsamındaki Tüketicilerin Bilinç Düzeylerine Göre Değişkenler}

Araştırma kapsamındaki tüketicilerin bilinç düzeylerine göre dağılımları Çizelge 12'de verilmiştir. Tüketicilerin bilinç düzeylerini ölçmek amacı ile 5'li Likert Ölçekli yargılar kullanılmıştır. Anket kapsamında tüketilere yöneltilen yargılar, geri dönüşüm ile ilgili olumsuz yargılar olarak verilmiştir. Anket sonucunda tüketicilerin bu olumsuz yargılara büyük oranda katılmadıkları görülmüştür. Araştırma kapsamındaki tüketiciler "geri dönüşüm yapmamanın çevre üzerindeki olumsuz etkileri umurumda değil" yargısına 1,4 (Kesinlikle Katılmıyorum) ölçek ortalaması ile kesinlikle katılmamaktadır. Tüketiciler, "geri dönüşüm yapmamanın sosyal etkileri umurumda değil" yargısına 1,4 (Kesinlikle Katılmıyorum) ölçek ortalaması ile kesinlikle katılmamaktadır. Tüketiciler, "geri dönüşüm yapmamanın ekonomik maliyeti umurumda değil" yargısına 1,5 (Biraz Katılmıyorum) 
ölçek ortalaması ile biraz katılmamaktadır. Tüketiciler, "geri dönüşüm yapmadığımda çıkan atık miktarı umurumda değil" yargısına 1,4 (Kesinlikle Katılmıyorum) ölçek ortalaması ile kesinlikle katılmamaktadır. Ölçek ortalamalarına bakıldığında tüm yargılarda kesinlikle katılmıyorum ve katılmıyoruma yakın dağılım olduğu anlaşılmaktadır. Sakarya Üniversitesi Siyasal Bilgiler Fakültesinde öğrenim gören 355 öğrencinin katıldığı bir çalışmada öğrencilerin birçok alanda geri dönüşüm bilincinin bulunmadığı ortaya konmuştur (Ak ve Genç, 2018). Kastamonu Üniversitesi Eğitim Fakültesi Sosyal Bilgiler bölümünde öğrenim gören öğrencilere yönelik yapılan 165 kişilik bir diğer çalışmada sosyal bilgiler öğretmenliği okuyan öğrencilerin geri dönüşüm ve katı atıklar konusunda bilincinin yetersiz olduğu tespit edilmiştir (Karatekin, 2014). Avustralya'da inşaat sektörüne yönelik yapılan 361 geçerli ankete ulaşılan bir çalışmada sektörün geri dönüşüm konusunda bilinç düzeyinin yüksek olduğu belirlenmiştir (Tam ve ark., 2018). Ankara'da tüketicilerin çevre bilincinin belirlenmesi amacıyla 399 geçerli ankete ulaşılan bir çalışmada tüketicilerin çevre bilincinin ortalamanın üstüne olduğu ortaya konmuştur (Yaraş ve ark., 2011).

Çizelge 12. Araştırma kapsamındaki tüketicilerin bilinç düzeylerine göre dağılımları (\%)

\begin{tabular}{|c|c|c|c|c|c|c|c|c|c|c|c|}
\hline \multirow[t]{2}{*}{$\mathrm{N}=415$} & \multicolumn{2}{|c|}{$\begin{array}{c}\text { Kesinlikle } \\
\text { Katıliyorum } \\
\text { (5) }\end{array}$} & \multicolumn{2}{|c|}{$\begin{array}{l}\text { Kat1liyorum } \\
\text { (4) }\end{array}$} & \multicolumn{2}{|c|}{$\begin{array}{c}\text { Nötr } \mathrm{Ne} \\
\text { Katıliyorum Ne } \\
\text { Katılmıyorum } \\
(3) \\
\end{array}$} & \multicolumn{2}{|c|}{$\begin{array}{l}\text { Katılmiyorum } \\
\text { (2) }\end{array}$} & \multicolumn{2}{|c|}{$\begin{array}{c}\text { Kesinlikle } \\
\text { Katılmıyorum } \\
(1)\end{array}$} & \multirow[t]{2}{*}{$\begin{array}{c}\text { Ölçek } \\
\text { Ortalaması }\end{array}$} \\
\hline & Say1 & $\begin{array}{c}\text { Yüzde } \\
(\%)\end{array}$ & Say1 & $\begin{array}{c}\text { Yüzde } \\
(\%)\end{array}$ & Say1 & $\begin{array}{c}\text { Yüzde } \\
(\%)\end{array}$ & Say1 & $\begin{array}{c}\text { Yüzde } \\
(\%)\end{array}$ & Say1 & $\begin{array}{c}\text { Yüzde } \\
(\%)\end{array}$ & \\
\hline $\begin{array}{l}\text { Geri dönüşüm } \\
\text { yapmamanın } \\
\text { çevre üzerindeki } \\
\text { olumsuz etkileri } \\
\text { umurumda değil. }\end{array}$ & 22 & 5,3 & 7 & 1,7 & 15 & 3,6 & 19 & 4,6 & 352 & 84,8 & 1,4 \\
\hline $\begin{array}{l}\text { Geri dönüşüm } \\
\text { yapmamanın } \\
\text { sosyal etkileri } \\
\text { umurumda değil. }\end{array}$ & 20 & 4,7 & 9 & 2,2 & 19 & 4,6 & 24 & 5,8 & 343 & 82,7 & 1,4 \\
\hline $\begin{array}{l}\text { Geri dönüşüm } \\
\text { yapmamanın } \\
\text { ekonomik } \\
\text { maliyeti } \\
\text { umurumda değil. }\end{array}$ & 21 & 5,1 & 14 & 3,4 & 24 & 5,8 & 28 & 6,7 & 328 & 79,0 & 1,5 \\
\hline $\begin{array}{l}\text { Geri dönüşüm } \\
\text { yapmadığımda } \\
\text { çıkan atık } \\
\text { miktarı } \\
\text { umurumda değil. }\end{array}$ & 18 & 4,3 & 9 & 2,2 & 19 & 4,6 & 25 & 6,0 & 344 & 82,9 & 1,4 \\
\hline
\end{tabular}

\section{Araştırma Kapsamındaki Tüketicilerin Farkındalıklarına Göre Değişkenler}

Araştırma kapsamındaki tüketicilerin farkındalıklarına göre dağılımları Çizelge 13'te verilmiştir. Tüketicilerin farkındalıkları belirlenirken olumlu yargılar verilmiştir ve tüketicilerin büyük oranda katıldıkları tespit edilmiştir. Araştırma kapsamındaki tüketiciler "geri dönüşüm doğal kaynakları korur" yargısına 4,9 (Kesinlikle Katılıyorum) ölçek ortalaması ile kesinlikle katılmaktadır. Tüketiciler, "geri dönüşüm çöpü azaltır" yargısına 4,9 (Kesinlikle Katılıyorum) ölçek ortalaması ile kesinlikle katılmaktadır. Tüketiciler, "geri dönüşüm enerji tasarrufu sağlar" yargısına 4,8 (Kesinlikle Katılıyorum) ölçek ortalaması ile kesinlikle katılmaktadır. Tüketiciler, "geri dönüşüm kirliliği azaltır" yargısına 4,9 (Kesinlikle Katılıyorum) ölçek ortalaması ile kesinlikle katılmaktadır. Tüketiciler, "geri dönüşüm atık depolama alanlarının gereksiz kullanımını azaltır" yargısına 4,8 (Kesinlikle Katılıyorum) ölçek ortalaması ile kesinlikle katılmaktadır. Tüketiciler, "geri dönüşüm çevre kalitesini artırır" yargısına 4,7 (Kesinlikle Katılıyorum) ölçek ortalaması ile kesinlikle katılmaktadır. Tüketiciler, "geri dönüşüm para tasarrufu sağlar" yargısına 4,7 (Kesinlikle Katıliyorum) ölçek ortalaması ile kesinlikle katılmaktadır. Tüketiciler, "geri dönüşüm gelecek nesiller için daha iyi bir çevre yaratır" yargısına 4,9 (Kesinlikle Katılıyorum) ölçek ortalaması ile kesinlikle katılmaktadır. Ölçek ortalamalarına göre tüm yargılarda kesinlikle katılıyoruma yakın dağılım vardır. Afyonkarahisar'da yer alan 4 ilköğretim okulunda öğrenim gören 109 anasınıfı öğrencisine (Yaşar ve 
ark., 2012) ve Karadeniz Bölgesi’nde bulunan bir üniversitede fen bilgisi öğretmenliği bölümünde öğrenim gören öğrencilerine (Harman ve Çelikler, 2016) yönelik yapılan çalışmalarda katılımcıların katı atıkların geri dönüşümü konusunda farkındalıklarının yüksek olduğu tespit edilmiştir. Türkiye'deki devlet ve vakıf üniversitelerinde öğrenim gören 394 öğrenciye yönelik çevrimiçi olarak düzenlenen bir başka çalışmada katılımcıların geri dönüşüm davranış algılarının ve geri dönüşüm davranışlarının önemine yönelik görüşlerinin yüksek seviyede olduğu belirlenmiştir (Birsen, 2020). Afrika'da yürütülen bir çalışmada (Kamara, 2006) tüketicilerin evsel atıkların çevreye yönelik etkileri konusundaki farkındalıklarının düşük seviyede olduğu tespit edilmiştir. Ankara Üniversitesi'nde öğrenim gören 651 lisans öğrencisinin katılm sağladığı bir çalışmada sağlık bilimleri alanında öğrenim gören öğrencilerin diğer bölümlerde okuyan öğrencilere göre katı atıklar konusunda daha yüksek farkındalık düzeyine sahip olduğu ortaya konmuştur (Talay ve ark., 2004).

Çizelge 13. Araştırma kapsamındaki tüketicilerin farkındalıklarına göre dağılımları (\%)

\begin{tabular}{|c|c|c|c|c|c|c|c|c|c|c|c|}
\hline \multirow[t]{2}{*}{$\mathrm{N}=415$} & \multicolumn{2}{|c|}{$\begin{array}{l}\text { Kesinlikle } \\
\text { Kat1liyorum } \\
(5)\end{array}$} & \multicolumn{2}{|c|}{$\begin{array}{l}\text { Katıliyorum } \\
\text { (4) }\end{array}$} & \multicolumn{2}{|c|}{$\begin{array}{l}\text { Nötr } \quad \mathrm{Ne} \\
\text { Kat1liyorum Ne } \\
\text { Kat1lmiyorum } \\
\text { (3) }\end{array}$} & \multicolumn{2}{|c|}{$\begin{array}{l}\text { Katılmiyorum } \\
\text { (2) }\end{array}$} & \multicolumn{2}{|c|}{$\begin{array}{l}\text { Kesinlikle } \\
\text { Katılmiyorum } \\
\text { (1) }\end{array}$} & \multirow[t]{2}{*}{$\begin{array}{l}\text { Ölçek } \\
\text { Ortalaması }\end{array}$} \\
\hline & Say1 & $\begin{array}{l}\text { Yüzde } \\
(\%)\end{array}$ & Say1 & $\begin{array}{l}\text { Yüzde } \\
(\%)\end{array}$ & Say1 & $\begin{array}{l}\text { Yüzde } \\
(\%)\end{array}$ & Say1 & $\begin{array}{l}\text { Yüzde } \\
(\%)\end{array}$ & Say1 & $\begin{array}{l}\text { Yüzde } \\
(\%)\end{array}$ & \\
\hline $\begin{array}{l}\text { Geri } \\
\text { dönüşüm } \\
\text { doğal } \\
\text { kaynakları } \\
\text { korur. }\end{array}$ & 377 & 90,8 & 27 & 6,5 & 7 & 1,7 & 2 & 0,5 & 2 & 0,5 & 4,9 \\
\hline $\begin{array}{l}\text { Geri } \\
\text { dönüşüm } \\
\text { çöpü } \\
\text { azaltır. }\end{array}$ & 375 & 90,4 & 22 & 5,3 & 16 & 3,9 & 1 & 0,2 & 1 & 0,2 & 4,9 \\
\hline $\begin{array}{l}\text { Geri } \\
\text { dönüşüm } \\
\text { enerji } \\
\text { tasarrufu } \\
\text { sağlar. }\end{array}$ & 357 & 86,0 & 38 & 9,2 & 14 & 3,4 & 3 & 0,7 & 3 & 0,7 & 4,8 \\
\hline $\begin{array}{l}\text { Geri } \\
\text { dönüşüm } \\
\text { kirliliği } \\
\text { azaltır. }\end{array}$ & 381 & 91,8 & 16 & 3,9 & 14 & 3,4 & 1 & 0,2 & 3 & 0,7 & 4,9 \\
\hline $\begin{array}{l}\text { Geri } \\
\text { dönüşüm, } \\
\text { atık } \\
\text { depolama } \\
\text { alanlarının } \\
\text { gereksiz } \\
\text { kullanımını } \\
\text { azaltır. }\end{array}$ & 371 & 89,4 & 27 & 6,5 & 10 & 2,4 & 4 & 1,0 & 3 & 0,7 & 4,8 \\
\hline $\begin{array}{l}\text { Geri } \\
\text { dönüşüm } \\
\text { çevre } \\
\text { kalitesini } \\
\text { artırır. }\end{array}$ & 379 & 91,3 & 0 & 0 & 11 & 2,7 & 2 & 0,5 & 23 & 5,5 & 4,7 \\
\hline $\begin{array}{l}\text { Geri } \\
\text { dönüşüm } \\
\text { para } \\
\text { tasarrufu } \\
\text { sağlar. }\end{array}$ & 340 & 81,9 & 47 & 11,3 & 20 & 4,8 & 4 & 1,0 & 4 & 1,0 & 4,7 \\
\hline $\begin{array}{l}\text { Geri } \\
\text { dönüşüm } \\
\text { gelecek } \\
\text { nesiller } \\
\text { için daha } \\
\text { iyi bir } \\
\text { çevre } \\
\text { yaratır. }\end{array}$ & 378 & 91,1 & 20 & 4,8 & 12 & 2,9 & 4 & 1,0 & 1 & 0,2 & 4,9 \\
\hline
\end{tabular}


Şenyurt ve arkadaşları (2011) tarafından Ege Üniversitesi’nde öğrenim gören 250 öğrenciye yönelik yapılan bir diğer çalışmada benzer şekilde sağlık bilimleri öğrencilerinin, fen ve sosyal bilimler öğrencilerine göre daha yüksek farkındalık düzeyine sahip olduğu belirlenmiştir. Türkiye'deki bir devlet üniversitesinde öğrenim gören 310 öğrenciye yönelik düzenlenen bir başka çalışmada öğrencilerin geri dönüşüm konusunda farkındalıklarının yüksek seviyede olduğu ortaya konmuştur (Dinçol Özgür, 2020). Rastgele seçilen 400 kişi ile Malta'da yapılan bir çalışmada tüketicilerin atıkların geri dönüştürülmediği durumda ortaya çıkacak sonuçlar karşısında farkındalığa sahip olduğu tespit edilmiştir (Bezzina ve Dimech, 2011).

\section{Sonuç ve Öneriler}

Bu çalışmada Türkiye'de yaşayan tüketicilerin geri dönüşüm konusundaki bilinç düzeylerinin ve farkındalıklarının araştırılması amaçlanmıştır. Bu amaçla Türkiye'deki tüketicileri temsilen basit tesadüfi örnekleme yöntemi ile seçilen 415 tüketici ile online anket çalışması gerçekleştirilmiştir. Araştırma sonuçlarına göre tüketicilerin üçte birinden fazlası $(\% 40,2)$ cam, kâğıt ve plastik atıklar için geri dönüşüm kutularının yerlerini bildiklerini belirtmişlerdir. Yine tüketicilerin yarıya yakını $(\% 48,4)$ eski giysi ve ayakkabılarını ihtiyaç sahiplerine ulaştırmak için giysi kumbaralarının yerlerini bildiklerini ve kullandıklarını belirtmişlerdir. Tüketicilerin \%30,1'i pil çöpü geri dönüşüm kutularının yerlerini bildiklerini belirtmişlerdir. Fakat araştırma kapsamındaki tüketicilerin yaklaşı üçte birinin $(\% 32,5)$ yaşadığı yerde veya günlük güzergahında pil çöpü geri dönüşüm kutusu olmadığı tespit edilmiştir. Aynı zamanda tüketicilerin yaklaşık yarısının $(\% 51,1)$ yaşadığı yerde veya günlük güzergahında elektronik atık toplama kutusu olmadığı ortaya konmuştur. Araştırma kapsamındaki tüketicilerin geri dönüşüm konusunda bilinç düzeylerinin ve farkındalıklarının yüksek olduğu tespit edilmiştir. Sonuçlar geri dönüşüm olanaklarına ücretsiz erişim ve kabul edilebilir bir mesafede geri dönüşüm olanaklarına erişimin tüketicilerin geri dönüşüm kararlarında önemli olduğunu göstermektedir. Çalışma kapsamında özellikle pil çöpü geri dönüşüm kutusu ve elektronik atık toplama kutularının sayılarının yetersiz olduğu görülmektedir. Pil çöpü ve elektronik atık toplama kutuları başta olmak üzere geri dönüşüm kutularının sayılarının artırılması gerekmektedir. Toplama noktasına olan mesafenin azaltılmasının, tüketicileri zaman maliyetinden kurtardığı ve geri dönüşüm davranışını artırdığı bilinmektedir. Ayrıca geri dönüşüm kutuları merkezi konumlara yerleştirilmelidir. Bunun için merkezi yönetim ve mahalli idarelerin harekete geçmesi beklenmektedir. Ayrıca tüketicilerin geri dönüşüm konusunda tutum ve niyetlerinin yüksek olduğu ve bunun geri dönüşüm davranışlarına yansıdı̆̆ tespit edilmiştir. Fakat Türkiye'deki geri dönüşüm davranış1 göstermek isteyen tüketicilerin bazı engeller ile karşılaştığı görülmektedir. Yeterli geri dönüşüm altyapısı sağlandıktan sonra, kamu spotları gibi teşvik edici ve geri dönüşüm yapılan atıklar için ödüllendirici (para iadesi, kentkarta para yüklenmesi gibi) sistemlerin devreye sokulması önerilmektedir.

Not: Bu çalışma 03-05 Haziran 2021 tarihlerinde gerçekleştirilen Uluslararası Küresel İklim Değişikliği adlı kongrede sözlü bildiri olarak sunulmuştur.

\section{Kaynaklar}

Ak, Ö., Genç, A.T., 2018. Üniversite öğrencilerinin geri dönüşüm bilinci üzerine bir araştırma: Sakarya üniversitesi örneği. Uluslararası Ekonomik Araştırmalar Dergisi. 4(2): 19-39.

Aksoylu, Z., Savlak, N. Y., Yanğıç, Ç., Çağındı, Ö., Köse, E., 2014. Manisa il merkezinde bireylerin ekmek çeşitlerini tüketim alışkanlıklarının belirlenmesi. Gıda. 39(3): 147-154.

Alhassan, H., Asante, F. A., Oteng-Ababio, M., Bawakyillenuo, S., 2018. Application of theory of planned behaviour to households' source separation behaviour in Ghana. Management of Environmental Quality: An International Journal. 29(4): 704-721.

Ara, S., Khatun, R., Uddin, M. S., 2021. Urbanization challenge: Solid waste management in Sylhet City, Bangladesh. International Journal of Engineering Applied Sciences and Technology. 5(10): 20-28.

Arain, A. L., Pummill, R., Adu-Brimpong, J., Becker, S., Green, M., Ilardi, M., ... \& Neitzel, R. L., 2020. Analysis of e-waste recycling behavior based on survey at a Midwestern US University. Waste Management. 105: 119-127.

Arıcı, H., 2006. İstatistik: Yöntemler ve Uygulamalar (Geliştirilmiş 16. Baskı). Ankara: Meteksan Matbaası.

Baş, T., 2010. Anket. Seçkin Yayıncılık, Ankara.

Başev, S. E., 2016. Recycling behaviour of students and the effect of sociodemographic characteristics on their behaviour. Global Media Journal: Turkish Edition. 6(12). 
Bayraktar, S., Çobanoğlu, E., 2016. Türkiye'de geri dönüşüm: 2006 ve 2012 yılları arasında tüketici motivasyonu, tutum ve davranışlarının karşılaştırmalı analizi. Akdeniz İİBF Dergisi. 16(33): 1-33.

Bendak, S., Attili, A. B., 2017. Consumers attitude and behavior towards domestic waste recycling in developing countries: A case study. Adv Recycling Waste Manag. 2: 124.

Bezzina, F. H., Dimech, S., 2011. Investigating the determinants of recycling behaviour in Malta. Management of Environmental Quality: An International Journal. 22(4): 463-485.

Birsen, V., 2020. Üniversite öğrencilerinin geri dönüşüm davranışlarına ilişkin görüş ve tutumlarının belirlenmesi. Yüksek Lisans Tezi, Çağ Üniversitesi Sosyal Bilimler Enstitüsü.

Björklund, A. E., Finnveden, G., 2007. Life cycle assessment of a national policy proposal-The case of a Swedish waste incineration tax. Waste Management. 27(8): 1046-1058.

Boone, H. N., Boone, D. A., 2012. Analyzing likert data. Journal of Extension. 50(2): 1-5.

Botetzagias, I., Dima, A. F., Malesios, C., 2015. Extending the theory of planned behavior in the context of recycling: The role of moral norms and of demographic predictors. Resources, Conservation and Recycling. 95: 58-67.

Byrne, S., O'Regan, B., 2014. Attitudes and actions towards recycling behaviours in the Limerick, Ireland region. Resources, Conservation and Recycling. 87: 89-96.

Corbin, J., Strauss, A., 2014. Basics of qualitative research: Techniques and procedures for developing grounded theory. Sage Publications.

Davis, G., Phillips, P. S., Read, A. D., Iida, Y., 2006. Demonstrating the need for the development of internal research capacity: Understanding recycling participation using the Theory of Planned Behaviour in West Oxfordshire, UK. Resources, Conservation and Recycling. 46(2): 115-127.

Dinçol Özgür, S., 2020. Öğretmen adaylarının geri dönüşüm farkındalıklarının çeşitli değişkenler açısından incelenmesi. Erzincan Üniversitesi Eğitim Fakültesi Dergisi. 22(3): 837-856.

Harman, G., Çelikler, D., 2016. Fen bilgisi öğretmen adaylarının geri dönüşüm kavramı hakkındaki farkındalıkları. Abant İzzet Baysal Üniversitesi Sosyal Bilimler Enstitüsü Dergisi. 16(1): 331-353.

Harman, G., Çelikler, D., 2018. The opinions of elementary science teacher candidates regarding the collection, separation and recycling of solid wastes. Kastamonu Eğitim Dergisi. 26(3): 813-822.

Harpe, S. E., 2015. How to analyze Likert and other rating scale data. Currents in Pharmacy Teaching and Learning. 7(6): 836-850.

Hoornweg, D., Bhada-Tata, P., 2012. What a waste: a global review of solid waste management. Urban development series; knowledge papers no. 15. Washington, DC: World Bank.

Hopper, J. R., Yaws, C. L., Ho, T. C., Vichailak, M., 1993. Waste minimization by process modification. Waste Management. 13(1): 3-14.

Joshi, A., Kale, S., Chandel, S., Pal, D. K., 2015. Likert scale: Explored and explained. British Journal of Applied Science \& Technology. 7(4): 396.

Kamara, A., 2006. Household participation in domestic waste disposal and recycling in the Tshwane metropolitan area: An environmental education perspective. University of South Africa, Pretoria.

Karatekin, K., 2014. Social studies pre-service teachers' awareness of solid waste and recycling. Procedia Social and Behavioral Sciences. 116: 1797-1801.

Knussen, C., Yule, F., MacKenzie, J., Wells, M., 2004. An analysis of intentions to recycle household waste: The roles of past behaviour, perceived habit, and perceived lack of facilities. Journal of Environmental Psychology. 24(2): 237-246.

Korum, U., 1971. Matematiksel İstatistiğe Giriş. Türkiye ve Orta Doğu Amme Enstitüsü Yayınları, No. 160, İkinci Basım, Sevinç Matbaası. Ankara.

Likert, R., 1932. A technique for the measurement of attitudes. Archives of Psychology. 22(140): 5-55.

Mahmud, S. N. D., Osman, K., 2010. The determinants of recycling intention behavior among the Malaysian school students: an application of theory of planned behaviour. Procedia-Social and Behavioral Sciences. 9: 119-124.

Newbold, P., Carlson, W., Thorne, B., 1995. Statistic For Business and Economics, by Prentice-Hall. Inc., NJ.

Prats, G. M., Garcia, Y. I. Á., Hernández, F. S., Zamora, D. T., 2020. Environmental Taxes. Its Influence on Solid Waste in Mexico. Journal of Environmental Management \& Tourism. 3(43): 755-762.

Seacat, J. D., Northrup, D., 2010. An information-motivation-behavioral skills assessment of curbside recycling behavior. Journal of Environmental Psychology. 30(4): 393-401.

Shevchenko, T., Laitala, K., Danko, Y., 2019. Understanding consumer E-waste recycling behavior: introducing a new economic incentive to increase the collection rates. Sustainability. 11(9): 2656.

Siwar, C., Hossain, A., Chamuri, N., 2000. Waste recycling and scavenging: review of concepts and practices for waste minimization in Malaysia. Paper presented at Conference on Environmental Management Issues and Challenges in Malaysia. 1: 25-26. 
Song, Q., Li, J., Zeng, X., 2015. Minimizing the increasing solid waste through zero waste strategy. Journal of Cleaner Production. 104: 199-210.

Statistical Office of the European Union (EUROSTAT), 2020. Recycling rate of municipal waste. Erişim Adresi: https://ec.europa.eu/eurostat/databrowser/view/t2020_rt120/default/table?lang=en Erişim Tarihi: 09.06.2021.

Şenyurt, A., Bayık, T., A., Özkahraman, Ş., 2011. Üniversite Öğrencilerinin Çevresel Konulara Duyarlılıklarının İncelenmesi, Süleyman Demirel Üniversitesi, Sağlık Bilimleri Enstitüsü Dergisi. 2(1): 8-15.

T.C Resmi Gazete (TCRG), 2019. Geri Kazanım Katılım Payına İlişkin Yönetmelik. (30995, 31 Aralık 2019). Erişim Adresi: https://www.resmigazete.gov.tr/eskiler/2019/12/20191231M4-4.htm Erişim Tarihi: 21.06.2021.

Tabernero, C., Hernández, B., Cuadrado, E., Luque, B., Pereira, C. R., 2015. A multilevel perspective to explain recycling behaviour in communities. Journal of Environmental Management. 159: 192-201.

Talay, İ., Gündüz, S., Akpınar, N., 2004. On the status of environmental education and awareness of undergraduate students at Ankara University, Turkey. International Journal of Environment and Pollution. 21(3): 293-308.

Tam, V. W., Le, K. N., Wang, J. Y., Illankoon, I. M., 2018. Practitioners recycling attitude and behaviour in the Australian construction industry. Sustainability. 10(4): 1212.

Tonglet, M., Phillips, P. S., Read, A. D., 2004. Using the Theory of Planned Behaviour to investigate the determinants of recycling behaviour: a case study from Brixworth, UK. Resources, Conservation and Recycling. 41(3): 191-214.

$\begin{array}{llll}\text { Türkiye } & \text { İstatistik } & \text { Kurumu } & \text { (TÜİK), }\end{array}$ http://www.tuik.gov.tr/Start.do;jsessionid=ml1RXrLHJh5LGV4LYGYp0KpRD8hnvl3GL7TLJJ7z1ndT Nryc4lrW!1724732474. Erişim Tarihi: 07.04.2020.

United States Environmental Protection Agency (EPA), 2021. Erişim Adresi: https://www.epa.gov/recycle Erişim Tarihi: 13.05.2021.

Üstündağlı, E., Güzeloğlu, E., 2015. Gençlerin Yeşil Tüketim Profili: Farkindalik, Tutum ve Davraniş Pratiklerine Yönelik Analiz. Global Media Journal: Turkish Edition. 5(10): 341-362.

Woollam, T. C., Emery, A., Griffiths, A. J., Williams, K. P., 2003. A comparison of intended and claimed recycling behaviour to actual, in a new kerbside scheme. CIWM Sci. Tech. Rev. 4: 2-9.

Yaraş, E., Akın, E., Şakacı, B. K., 2011. Tüketicilerin Çevre Bilinci Düzeylerini Belirlemeye Yönelik Bir Araştırma. Öneri Dergisi. 9(35): 117-126.

Yaşar, M. C., İnal, G., Kaya, Ü. Ü., \& Uyanık, Ö. (2012). Çocuk gözüyle tabiat anaya geri dönüş. Eğitim ve Öğretim Araştırmaları Dergisi. 1(2): 30-40. 